\title{
Tuberous breast: Morphological study and overview of a borderline entity
}

\author{
Marco Klinger $M D^{1}$, Fabio Caviggioli $M D^{1}$, Francesco Klinger $M D^{1}$, \\ Federico Villani MD ${ }^{1}$, Erseida Arra MD ${ }^{1}$, Luca Di Tommaso MD²
}

\begin{abstract}
M Klinger, F Caviggioli, F Klinger, F Villani, E Arra, L Di Tommaso. Tuberous breast: Morphological study and overview of a borderline entity. Can J Plast Surg 2011;19(2):42-44.
\end{abstract}

BACKGROUND: Tuberous breasts are widely known and described. Several surgical strategies have been proposed; however, few studies explain the origin or structural alterations of this deformity. No histological studies have been performed. The present article describes a morphological and histological study of breast tissue specimens.

METHODS: Mammary specimens of 22 female and five male patients with tuberous breasts were histologically analyzed and compared with six specimens harvested from normal female breasts and from three cases of true 'normal' gynecomastia.

RESULTS: A high prevalence of one histological subtype was observed, with the presence of collagen fibres among few fibroblasts. Histochemical analysis highlighted alterations of the arrangement and of the quantity of collagen involving breast structures.

CONCLUSIONS: Results of the present study suggest that collagen deposition alterations can better explain breast parenchyma modifications. Histological features of male subjects support this theory. Additionally, the observation of two cases in male homozygous twins suggests the role of genetic influences.

Key Words: Breast; Breast diseases; Gynecomastia; Histocytochemistry

\section{Les seins tubéreux : étude morphologique et aperçu d'une entité limite}

HISTORIQUE : Les seins tubéreux sont bien connus et bien décrits. Plusieurs stratégies chirurgicales sont proposées, mais peu d'études expliquent l'origine ou les altérations structurelles de cette malformation. Aucune étude histologique n’a été effectuée. Le présent article décrit une étude morphologique et histologique d'échantillons de tissus mammaires. MÉTHODOLOGIE : Des spécimens mammaires de 22 femmes et de cinq hommes ayant des seins tubéreux ont fait l'objet d'une analyse histologique et ont été comparés à six spécimens prélevés sur des seins normaux de femmes et à trois cas de véritables gynécomasties « normales ».

RÉSULTATS : On a observé la forte prévalence d'un sous-type histologique, avec la présence de fibres de collagène dans quelques fibroblastes. L'analyse histochimique a fait ressortir des altérations dans la disposition et la quantité de collagène dans les structures mammaires.

CONCLUSIONS : D'après les résultats de la présente étude, les altérations des dépôts de collagène expliqueraient mieux les modifications du parenchyme mammaire. Les caractéristiques histologiques des sujets de sexe masculin appuient cette théorie. De plus, l'observation de deux cas chez des jumeaux homozygotes de sexe masculin laisse croire à une influence génétique.
T uberous breasts are one of the parenchymal malformations that have been widely described $(1-14)$. This alteration, which only appears during growth, often involves both breasts, with a high incidence of asymmetry (6).

In the literature, many studies $(1,6,8-10,12-16)$ have proposed different surgical strategies to correct this deformity; however, only a few studies (6) explain its origins or structural alterations. The prevailing hypothesis suggests that an abnormal thickening of the fascia corporis leads to a condition that might influence an alteration in glandular development. In fact, this stenosis limits horizontal parenchyma growth, ultimately leading the breast to acquire the typical clinical aspect.

In patients admitted for surgical treatment for tuberous breast correction, our observations show similar and typical features for all cases: diffuse bleeding, glandular herniation at surgery, widespread fibrosis causing parenchymal adhesion to the derma, muscular fascia and 'tissue memory', often prone to relapse. Such observations led us to hypothesize that the alterations of the fascia corporis in tuberous breasts could not be a satisfactory explanation for the typical features of this syndrome because there were other alterations that extensively involved all components of the mammary gland.

In view of the absence of histological studies regarding this entity, we performed a study of tuberous breast parenchyma to investigate and evaluate structural alterations and to identify the real alteration causing this malformative syndrome, which is often difficult, but fascinating to solve.

Moreover, we have encountered comparable surgical alterations in breasts whose clinical appearance does not appear to be related to a typical tuberous breast, but whose microscopic analysis, not included in the present article, has shown similar features. This is the reason why we propose to define a new entity titled 'borderline tuberous breast'.

\section{METHODS}

The present study included 22 female and five male patients with tuberous breasts, from first to third degree according to the Toulouse classification (6), and compared them with six women with normal breasts (group A, controls) and three men with true gynecomastia (group B, controls) (Table 1). The average age of both groups was 30.3 years.

Patients with metabolic disorders, autoimmune diseases, or HIV, hepatitis $\mathrm{B}$ or $\mathrm{C}$ virus positive were excluded.

During surgical intervention, specimens of the parenchyma were harvested from the central and inferior mammary quadrants to analyze the gland and fascia corporis.

After paraffin embedding, slices of $5 \mu \mathrm{m}$ thickness were stained with hematoxylin and eosin, and underwent histochemical procedures to reveal collagen fibres (Masson's trichrome), elastic fibres (Orcein stain) and amyloid deposition (Congo red stain).

Gross features

\section{RESULTS}

Tuberous breast patients (group A) showed macroscopic features that were divided into two subgroups: the first (A1) characterized by irregular edges in nodular areas, white coloured and firmer than surrounding tissue lacking adipose tissue (16 cases, 57.14\%); and the second (A2) characterized by white elastic fibres among adipose tissue (12 cases, $42.86 \%$ ) (Table 2).

\footnotetext{
${ }^{1}$ Plastic Surgery Unit; ${ }^{2}$ Department of Pathology, University of Milan, IRCCS Istituto Clinico Humanitas, Rozzano, Milano, Italy

Correspondence: Dr Fabio Caviggioli, Università degli Studi di Milano - Cattedra di Chirurgia Plastica, IRCCS Istituto Clinico Humanitas -

U.O. Chirurgia Plastica 2, Via Manzoni, 56-20089 Rozzano, Milano, Italy. Telephone 390282244072 or 390282246443,

fax 390282242298, e-mail fabio.caviggioli@humanitas.it
} 
TABLE 1

Study demographics

\begin{tabular}{llcc}
\hline Group & Pathology & Patients, $\mathbf{n}$ & Specimens, $\mathbf{n}$ \\
\hline Cases & Tuberous breasts & 28 & 112 \\
Controls & $\begin{array}{l}\text { Gigantomastia and true } \\
\text { gynecomastia }\end{array}$ & 9 & 32 \\
& & & \\
\hline
\end{tabular}

TABLE 2

Results of the histological examination

\begin{tabular}{|c|c|c|c|c|c|c|}
\hline & \multicolumn{3}{|c|}{ Subset A1 } & \multicolumn{3}{|c|}{ Subset A2 } \\
\hline \multicolumn{7}{|c|}{ Gross examination } \\
\hline & \multicolumn{3}{|c|}{$\begin{array}{l}\text { Whitish nodular areas, } \\
\text { poorly defined borders }\end{array}$} & \multicolumn{3}{|c|}{ Whitish tread, elastic texture } \\
\hline & \multicolumn{3}{|c|}{ Scarce adipose tissue } & \multicolumn{3}{|c|}{ Increased presence of adipose tissue } \\
\hline \multicolumn{7}{|c|}{ Microscopic examination } \\
\hline \multicolumn{7}{|c|}{ Low magnification } \\
\hline \multirow[t]{2}{*}{ Stroma } & Glands & & Glands & Findings & $\begin{array}{l}\text { Neuro } \\
\text { bundles }\end{array}$ & $\begin{array}{r}\text { Fibrous } \\
\text { tissue }\end{array}$ \\
\hline & Absent & & Lowered & Normal & $\begin{array}{l}\text { Adipose } \\
\text { tissue }\end{array}$ & $\begin{array}{l}\text { Adipose } \\
\text { tissue }\end{array}$ \\
\hline \multicolumn{7}{|c|}{ High magnification } \\
\hline \multirow[t]{2}{*}{ Fibroblast } & Lowered & & Normal & Findings & Increase & Normal \\
\hline & Parallel & & Dis & Normal & Dis & Dis \\
\hline \multirow[t]{2}{*}{ Matrix } & AA1 & AA2 & $A B$ & B1 & B2 & B3 \\
\hline & Increase & Amorph & Increase & Normal & $\begin{array}{l}\text { Neuro } \\
\text { fibres }\end{array}$ & $\begin{array}{l}\text { Small } \\
\text { adipocytes }\end{array}$ \\
\hline Patients, $\mathrm{n}$ & 11 & 4 & 1 & 5 & 1 & 6 \\
\hline
\end{tabular}

Amorph Amorphous; Dis Disoriented

Specimens harvested from the control group (group B) were characterized by fibres or irregular areas, and were white in colour with elastic fibres among abundant adipose tissue.

\section{Microscopic features}

Subset A1: In 15 patients, it was observed that the nodular areas were characterized by rare fibroblasts with parallel disposition and abundant extracellular matrix with short eosinophil bundles (Figure 1).

In four of these patients (AA2), amorphous material was found. The glandular elements had a peripheral dislocation from a stroma condensation. With histochemical procedures, only collagen fibres (no elastic ones) were shown in the extracellular matrix (Figures 2 and 3). No amyloid was found in the cases with amorphous material.

Only in one patient $(A B)$, the nodular area was characterized by an area with poorly defined borders with some disorientation and varying fibroblasts, with extracellular matrix greater than normal and few glands. On histochemical analysis, both collagen and elastic fibres were identified in the stroma.

Subset A2: In five patients, adipose and fibrous tissue with normal features were identified using histological methods.

In one patient, the lesion consisted of disoriented, bundled fibroblasts, with further neurobundles of different calibre and length (Figure 4). The histochemical analysis showed both collagen and elastic fibres.

In six patients, the lesion consisted of fibrous and adipose tissue proliferation with disoriented fibroblasts, small and thickened adipocytes, and an extracellular matrix composed of collagen and elastic fibres.

\section{DISCUSSION}

Snoopy breasts $(6,9)$, tubular breasts $(1,6,8)$, herniated areolar complexes $(6,8-10)$ and constricted breasts $(8)$ are some of the synonyms that have been used to describe tuberous breast, leading to confusion and misunderstanding. Indeed, these terms describe different appearances of the same entity. Similarly, numerous surgical techniques have been proposed to treat this deformity. Conversely, there are few studies

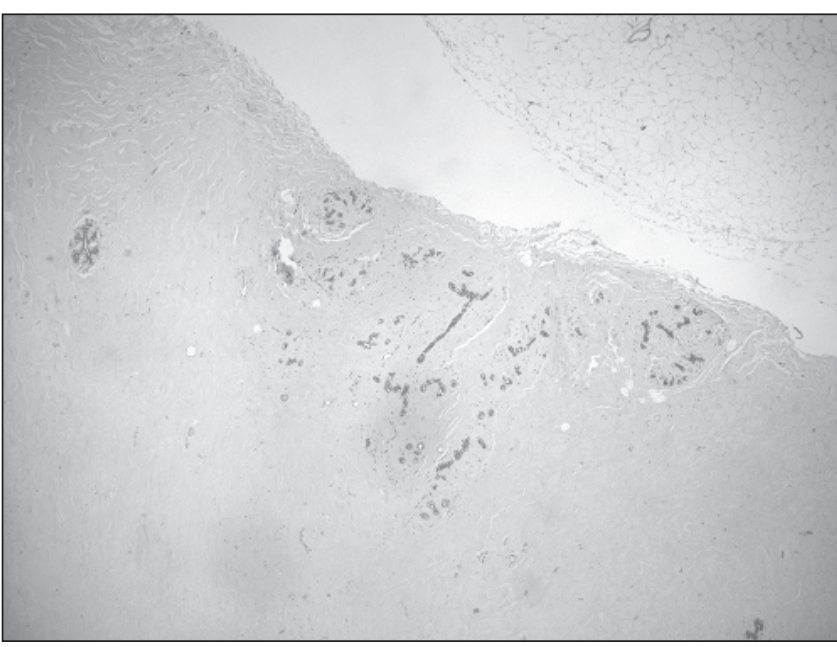

Figure 1) Subset A1, with rare fibroblasts and abundant eosinophil matrix. Hematoxylin and eosin stain, original magnification $\times 4$

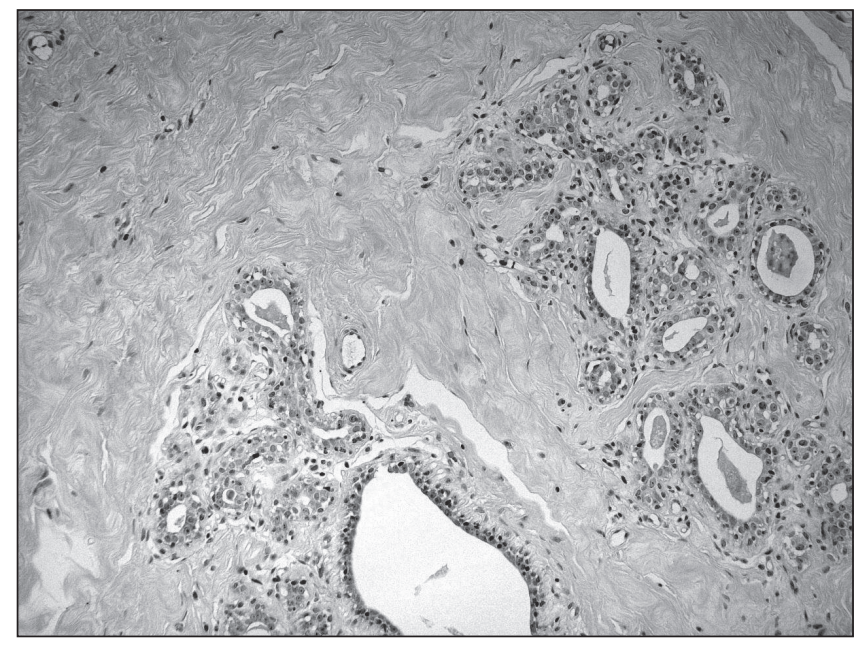

Figure 2) Prevalence of collagen fibres in the extracellular matrix. Masson's trichrome stain, original magnification $\times 20$

that aim to clarify the etiology. The prevailing theory explains this malformation as an abnormal thickening of the fascia corporis, which constricts glandular development at the base of the breast, causing areolar herniation.

In our clinical and surgical practice, we have observed that patients with tuberous breasts manifested, in addition to the above features, skin, parenchyma, fascia and vascular alterations. This evidence led us to carefully investigate the possible etiological elements. In fact, in our surgical experience with tuberous breasts, we have never found ringlike fascia constriction. The results of our analysis show significant differences in quantity and disposition of collagen fibres in patients with tuberous breasts versus normal breasts. In fact, collagen fibres appear altered in disposition and quantity, occasionally assembled in bundles determining the typical glandular toughness, ligament and fascial thickening and general fibrosis. Furthermore, we have excluded amyloid build-up. That is why, after histochemical confirmation, we believe that the etiopathology is a result of an alteration of collagen deposition. Again, these alterations appear to involve nearly all the breast stroma and not only the fascia, making tuberous breast a complex and multilayer malformation.

The presence of tuberous breasts in males, in which the stroma is the main component of breast parenchyma and where we demonstrated altered collagen deposition, in addition to the similarity between male and female subjects, further support this theory. 


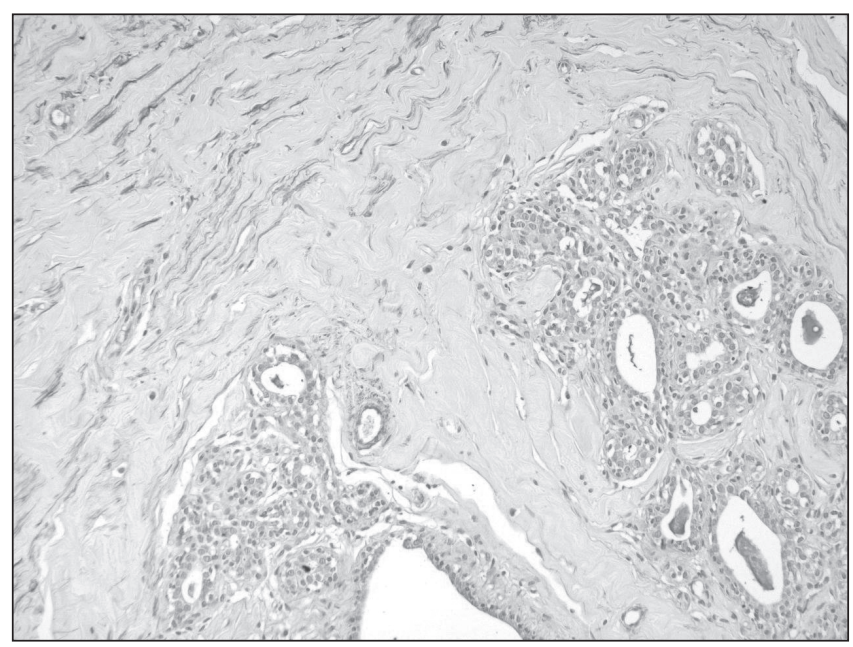

Figure 3) Absence of elastic fibres (usually coloured black with Orcein stain, original magnification $\times 20$ )

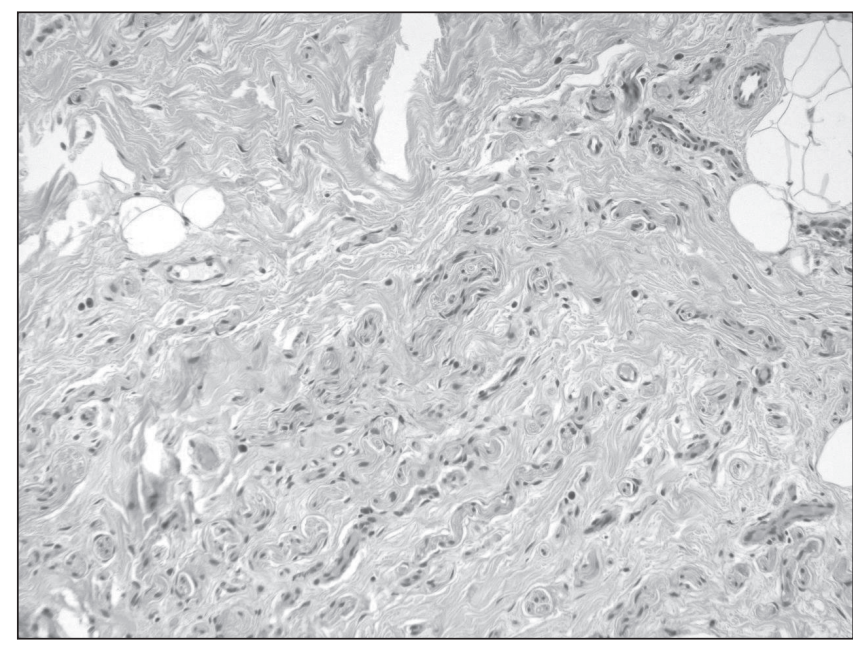

Figure 4) Disoriented fibroblasts with neurobundles of different calibre. Hematoxylin and eosin stain, original magnification $\times 20$

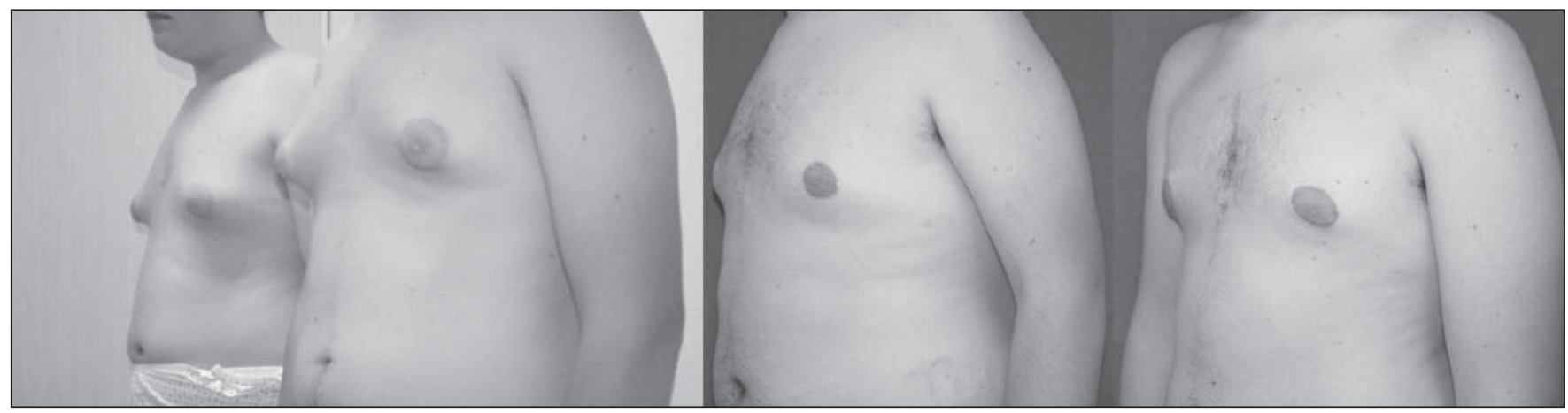

Figure 5) Male twin patients presenting tuberous breasts in true gynecomastia, pre-and postoperatively at six months

Moreover, the presence of tuberous breasts in homozygous twins examined in our study suggests that an underlying genetic component promotes altered collagen fibre production, implying familial transmission of the pathology (Figure 5).

In our practice, we have noticed that breasts not considered 'tuberous' according to their clinical appearance or definition, display a typical surgical pattern. These clinical data were confirmed by microscopic observation of tissue specimens. We consider this entity to be a 'borderline tuberous breast' - difficult to recognize, but one that must be adequately corrected to reduce complications and relapses.

Our preliminary results seem interesting and should be confirmed by a larger case study and further analysis with an ultrasonic study.

\section{REFERENCES}

1. Rees TD, Aston S. The tuberous breast. Clin Plast Surg 1976;3:339-46.

2. Bostwick J III. Plastic and Reconstructive Breast Surgery.

St Louis: Quality Medical Publishing Inc, 1990:60-97.

3. Arey LB. Developmental Anatomy. Philadelphia: WB Saunders, 1941.

4. McCarthy JG. Plastic Surgery. Philadephia: WB Saunders, 1990:3839-43.

5. Haagensen CD. Diseases of the Breast, 4th edn. Philadelphia: WB Saunders, 1990.

6. Grolleau JL, Lanfrey E. Breast anomalies: Treatment strategy for tuberous breast, minor deformities and asymmetry.

Plast Reconstr Surg 1999;104:2040-8.

7. Mandrekas AD, Zambacos GJ. Aesthetic reconstruction of the tuberous breast deformity. Plast Reconstr Surg 2003;112:1099-108.

8. von Heimburg D, Exner K. The tuberous breast deformity: Classification and treatment. Br J Plast Surg 1996;49:339-45.

9. Gasperoni C, Salgarello M. Tubular breast deformità: A new surgical approach. Eur J Plast Surg 1987;9:141-4.

\section{CONCLUSION}

The present study yielded interesting preliminary results.

First, our data suggest a disorder in collagen deposition as the cause of this condition; second, all of the stromal components (derma, gland, adipose tissue and fascia) seem to be involved; third, the typical relapse complications, the characteristic bleeding, the structural adherence and fibrosis from derma to fascia may be better explained by this theory; and fourth, a borderline presentation of this entity should be recognizable.

Finally, the results obtained from the examination of homozygous twins in the present case study suggest the possibility of genetic influences and subsequent familial transmission of this condition.

10. Temourian B, Adham MN. Surgical correction of the tuberous breast. Ann Plast Surg 1983;10:190-9.

11. Von Heimburg D. Refined version of the tuberous breast classification. Plast Reconstr Surg 2000;105:2269-70.

12. Longacre JJ. Correction of the hypoplastic breast with special reference to reconstruction of the "nipple type breast" with local dermofat pedicle flap. Plast Reconstr Surg 1954;14:431-41.

13. Versaci AD, Rozzelle AA. Treatment of tuberous breast utilizing tissue espansion. Aesth Plast Surg 1991;15:307-12.

14. Scheepers JH, Quaba AA. Tissue espansion in the treatment of tubular breast deformity. Br J Plast Surg 1992;45:529-32.

15. Williams G, Hoffman S. Mammoplasty for tubular breast. Aesth Plast Surg 1981;5:51-6.

16. Elliot MP. A muscolocutaneous transposition flap mammaplasty for correction of the tuberous breast. Ann Plast Surg 1988;20:153-7. 